\title{
Natural Disasters and Adaptation to Climate Change
}

\author{
Edited by Sarah Boulter, Jean Palutikof, David Karoly, and Daniela Guitart
}




\section{Table of Contents}

1 Introduction

Jean Palutikof, David Karoly, Sarah Boulter, and Daniela Guitart

2 Climate change and disaster risk management: challenges and opportunities

8

Madeleine C. Thomson

\section{Part I Case Studies from North America}

A few words on Andrew Garcia 33

3 Hurricane Katrina and the city of New Orleans $\quad 34$

Andrew W. Garcia

4 A brief history of flooding and flood control measures along the Mississippi river

basin, USA

Timothy M. Kusky

5 The 2003 and 2007 wildfires in southern California

Jon E. Keeley, Alexandra D. Syphard, and C. J. Fotheringham

6 Adapting to extreme heat events: 30 years of lessons learned from the Kansas

85

City, Missouri, extreme heat program

David M. Mills and William D. Snook

\section{Part II Case Studies from Australia}

7 Drought and water in the Murray-Darling Basin: from disaster policy to

100 adaptation

Linda C. Botterill and Stephen Dovers

8 After 'Black Saturday': adapting to bushfires in a changing climate

115

Joshua Whittaker, John Handmer, and David Karoly

9 Cyclone Tracy and the road to improving wind resistant design

Matthew Mason, Katharine Haynes, and George Walker

10 Adaptation and resilience in two flood prone Queensland communities

150

David King, Armando Apan, Diane Keogh, and Melanie Thomas

\section{Part III Case Studies from Europe}

11 The most costly natural hazard in Europe: windstorms

Uwe Ulbrich, Gregor C. Leckebusch, and Markus G. Donat

12 The 2003 heat wave: impacts, public health adaptation and response in France

189

Mathilde Pascal, Alain Le Tertre, and Karine Laaidi

13 Lessons from river floods in central Europe, 1997-2010

203

Zbigniew W. Kundzewicz

14 Lessons learned from the North Sea flooding disaster in the Netherlands, 1953

218

Pier Vellinga and Jeroen Aerts 


\section{Part IV Case Studies from the Developing World}

15 Adapting to drought in the West African Sahel 235

Simon P. J. Batterbury and Michael J. Mortimore

16 The 2004 Indian Ocean tsunami: Sri Lankan experience 252

Sam S. L. Hettiarachchi and W. Priyan S. Dias

17 Recovery efforts: the case of the 2007 cyclone Sidr in Bangladesh 264

Bimal K. Paul and Munshi K. Rahman

18 Coffee, disasters, and social-ecological resilience in Guatemala and Chiapas, 276 Mexico

Hallie Eakin, Helda Morales, Edwin Castellanos, Gustavo Cruz-Bello, and Juan F. Barrera

19 Responding to floods in the Nile Basin: a case study of the 1997/98 floods in the Upper White Nile

Marisa C. Goulden and Declan Conway

20 Floods in the Yangtze river basin, China

Zbigniew W. Kundzewicz, Jiang Tong, and Su Buda

\section{Part V Synthesis Chapters}

21 Disasters and development Jessica Ayers, Saleemul Huq, and Sarah Boulter

22 What next? Climate change as a game-changer for policy and practice Karen O'Brien and Thomas E. Downing

23 Barriers and limits to adaptation: cautionary notes Jon Barnett, Colette Mortreux, and W. Neil Adger

24 Lessons learned for adaptation to climate change 387 Sarah Boulter, Jean Palutikof, and David Karoly

25 Afterword: floods, storms, fire and pestilence - disaster risk in Australia during 412 2010/11 David Karoly and Sarah Boulter 
Sarah Boulter, Jean Palutikof, David Karoly, and Daniela Guitart (eds.) 2013 in press. Natural

Disasters and Adaptation to Climate Change. Cambridge University Press.

\title{
Ch. 15 Adapting to drought in the West African Sahel
}

\author{
S. P. J. Batterbury and M. J. Mortimore \\ Dept of Resource Management and Geography, University of Melbourne and Drylands \\ Research, UK (MM) \\ Simonpjb@unimelb.edu.au
}

\subsection{Introduction}

Local responses to drought in the West African Sahel tell a remarkable story, in which local adaptive capacity has proven equal to the challenges of living in a harsh and drought-prone environment. This chapter outlines the extent of this capacity, and argues that it should be facilitated and celebrated.

The Western Sahel is a vast and populous dryland region running east-west between the Sahara desert to the north and the West African forest zone to the south. A 'band' of broadly similar climatic conditions run from Senegal to the shores of Lake Chad. Travelling north from the West African coast, rainfall diminishes and average biomass decreases. Despite its remoteness, population density is moderate, and high around urban centres. The region has been traversed by armies, traders, and new settlers for thousands of years. There are a diversity of cultures, languages, political entities and production systems. Rural livelihood systems are based on rainfed agriculture and pastoralism, always influenced by climatic hazards: drought and temperature extremes, and occasional flooding and high winds. The rural heartland also produces food for markets and growing urban areas, the largest in the drylands being the cities of Dakar, Bamako, Ouagadougou, Niamey and Kano.

Dryland adaptation is deep-seated among Sahelian peoples. Food shortages, occasioned by insufficient precipitation to nourish crops, sometimes extend into famine after extremely dry years, and these are common over the long term record of human occupation. It is important to understand the concrete responses that individuals and households make, faced with seasonal and longer-term climatic risks (Mortimore, 1989). Negotiating the drought has been pursued outside the public gaze - often unceremoniously - through what anthropologist Paul Richards calls 'unsupervised learning' at the local scale (Richards, 2010, p. 18), and through the transmission of learned practices to others. Local people have found ways to minimise the risk of lost food production, and have initiated a gradual and sometimes vibrant expansion of commercial activity, alongside increasing reliance on remittances from migration. Their strategies also involve circumventing the disruptive effects of the expropriation of productive assets by governments and some private actors. On occasion, outside knowledge has blended well with local expertise to enhance agricultural resilience. For example, animal health protection and provision of water points are present in a few drier pastoral areas, and have proven valuable unless over-exploited.

\subsection{The Sahel - physical characteristics and drought}

Over millennia, the Sahel has seen several phases of drying and wetting, now thought to be linked to the strength of the Atlantic Meridional Overturning Circulation. These phases have in turn influenced human settlement and migration, with a population exodus during drier periods (Mulitza et al. 2008; Castañeda et al., 2009). Aridity and rainfall variability increase with latitude. In the absence of irrigation, crop production is limited to where average annual rainfall 
is more than 250-300 mm (Sahel Working Group, 2007). North of this is the pastoral zone, with seasonal grazing possible in drier conditions.

The rainfall trend over the past century has exhibited relatively abrupt changes in direction, with a multidecadal wet period (1951-1968) followed by a severe drying period from the late 1960s to the 1990s. There has since been a rainfall recovery but with further dry years (Figure12.1).

The decreasing rainfall and intensity of the droughts in the Sahel from the 1970s to the 1990s, and the extent of the downward trend in rainfall, are the most significant recent climate change recognised by climatologists (Dai et al. 2004).

In particular, unreliability has characterised the last forty years, with a punishing drought from 1972-1974. There was a further, deeper dry period in the mid-1980s for which farmers and governments were better prepared. From the mid-1960s to the mid-1990s, annual rainfall declined by 25-30 \% depending on location (Figure 15.1). The east-west isohyets of mean annual rainfall migrated southwards by up to $100 \mathrm{~km}$ (Mortimore, 2010). From 1968 growing seasons were significantly shortened by late starts and early finishes.

Future climatic change in the Sahel is uncertain, with some disagreement among climate models. However, models do not agree on the sign (direction) of change in future - while some predict a persistently dry regime, others predict an improvement (Giannini et al., 2008).

\section{[Insert Figure 15.1 around here]}

\subsection{Responses to drought in Northern Nigeria in the 1970s}

Northern Nigeria provides the evidence that Sahelian societies adapt to drought hazard over time, and it is a region where little national or international aid has assisted this process. The drought-prone region now has 30-40 million people (Mortimore, 2010). Farming and herding include significant commercial production. In the 1960s when rains were good, the region saw booms in commercial groundnut and cotton, and this diverted labour and land from food crops, as it had in 1914 and 1927 (Watts, 1983). The 1972-1974 drought was punishing, and the plight of rural households was real. Granaries were emptied, sometimes for years. People ate the leaves of trees and herbs, or sold livestock and other valued possessions to buy cassava flour at market as a substitute for grain (Mortimore, 1989; Mortimore and Adams, 2001). Some families went to the towns to beg, especially livestock herders. There was widespread undernutrition, and very high livestock mortality. The government seemed powerless or unwilling to help. In 1974 the Nigerian states distributed grain, enough to offer a few meals for the luckier families; stories of corruption and misallocation abounded. Ironically, food aid was glimpsed passing by on trucks in transit to Niger to the north, where the international media has focused world attention.

As the severity of the food shortage deepened, individuals and households adjusted on a trajectory of diminishing reversibility. Offering labour to others for food or cash, gathering famine foods or getting help from kin, gradually gave way in time to selling livestock, pledging or selling land, and eventually, begging and migrating as a family to more promising regions. The routine use of 'famine foods' was extended dramatically (Mortimore, 1989, p. 67-74).

Given the situation that prevailed, is it correct to paint the drought cycle of 1972-1974 as evidence of the failure of adaptive strategies? Or were these strategies temporarily overwhelmed 
Sarah Boulter, Jean Palutikof, David Karoly, and Daniela Guitart (eds.) 2013 in press. Natural

Disasters and Adaptation to Climate Change. Cambridge University Press.

by the severity of the drought, yet they remained resilient? Did people learn from their severe hardships?

\subsection{From coping to adaptation strategies}

The evidence is that short-term coping feeds into enduring adaptive strategies for managing variable rainfall and bio-productivity. Central to this is reduced reliance on rainfall (Batterbury and Forsyth, 1999). This was particularly important when very severe Sahel drought returned from 1982-1984 (Figure 15. 1). A basic model suggests a sequence of stepwise diversification strategies are followed;

1. Farmers negotiate rainfall each year. Pearl millet is the most drought resistant of all the crops grown in the Sahel. Farmers manage their own gene pool, by selecting and storing the best seed (Busso et al., 2000). Diversity in landraces is a recognised defence against disease, pests and climatic hazards. Cropping patterns and labour allocation are finely judged according to rainfall, particularly for weeding. In some wetter areas, productivity rises with population density (rather than the reverse), such that families now practice sustainable intensification on tiny plots (at less than 0.5 ha per capita) (Adams and Mortimore, 1997). What matters most - more than rainfall is a farmer's ability to mobilise enough labour to meet peak requirements, and to access enough organic material to sustain soil biological health (Mortimore, 2006).

2. For farmers and herders alike, livestock are a repository for savings, a reserve for contingencies, a self-reproducing asset, a source of income, and energy. Livestock herding is less sensitive than crop production to climatic changes (Mertz et al., 2010). Animals also support intensification on the farm (through the cycling of nutrients through crop residues and manure, although human labour input is high when animals are stall-fed). Animals are bred for their drought and disease tolerance, and grazing performance under variable conditions (Kratli, 2008). Over the last 30 years, there has been a shift to small ruminants (sheep and goats) across the Sahel, as they are less costly, hardier, easier to feed, and reproduce more quickly than cattle (de Leeuw et al., 1995).

3. Business. To minimise risk from crop failure, and to tackle poverty, alternative livelihoods and sources of income are necessary and desirable. Almost all individuals in four Nigerian villages surveyed in the mid-1990s had income from trading, making articles for sale, or providing services (Mortimore and Adams, 2001). Incomes may be small, but are important in the preharvest season when granaries are depleted. Women are increasingly turning to small scale business, including food sales and small-scale trading, as a study of Zarma households in Niger showed (Batterbury, 2001). Onions, tomatoes and mangoes are increasingly grown for sale to urban centres, which continue to grow in size (Sahel Working Group, 2007).

4. Greater degrees of livelihood diversification include non-local activities. They are associated with high levels of mobility between rural communities, towns and cities, and commercial farms. As part of diversifying away from subsistence activities, human mobility has increased with the high rates of urbanisation and better transport (modern vehicles, and more surfaced roads). This does not indicate the failure of rural livelihoods but rather their success; drought requires a diversified portfolio of activities (Figure 15.2). The exception is 'distress migration' in the worst years of food insecurity in the 1970s, when thousands of single men, and some families, moved south away from the drought, in search of work. 


\subsection{Productive bricolage}

Stepwise diversification of livelihood activities (Figure 15.2) occurs as drought conditions worsen. Nonetheless in less difficult years, it is actually easier for households to pursue multiple strategies at the same time and this process becomes less linear and more complex. Tailoring adaptive drought management to circumstances therefore involves productive bricolage, the controlled mixing of income sources and subsistence activities (Batterbury, 2001). To operate these strategies requires astute management of scarce capital, and an institutional space that permits negotiation amongst household members. This assures scarce labour demands are met, and opportunities are exploited.

New technology and infrastructure can facilitate bricolage. Across the Sahel, mobile phones not present in the 1970s and 1980s -facilitate communication between household members, particularly over price information for sales and purchases, and labour management. Seasonal climate forecasting is gaining in accuracy but is still not available to the majority of Sahelian farmers and herders (Tacko Kandji et al., 2006).

At the same time, political and economic forces confound productive bricolage. Conflict in Côte d'Ivoire, for example, has curtailed a favoured migration route for young Burkinabè men. In the 1990s their remittances balanced the Burkina Faso economy, being $6 \%$ of GDP. The response to blocked labour migration routes is usually swift. Due to the conflict, travel increased to Libya's oil towns. The European Union tightened its borders to deny travel further northward than Morocco, increasing movement to Libya (Bredeloup and Pliez, 2011). Political uncertainty in 2011 has ceased this livelihood opportunity. Similarly, oil-rich central Africa currently hosts growing numbers of temporary Sahelian workers in Gabon and neighbouring countries.

There are also unwelcome losses of good agricultural land, to agri-food development for external markets on the few large irrigation schemes in the Sahel. Urban and foreign buyers are currently securing large holdings in more productive areas as investments, although these are not as extensive as in Eastern and Southern Africa and some production is destined to supply local urban areas (Hilhorst et al., 2011).

It seems certain that Sahelian households will need more opportunities for diversification in future, as even the coastal and North African migration destinations have become more constrained. This is particularly true for populations in Burkina Faso, Niger and Mali that have historically relied on long term migration to the labour markets of the francophone West African coast. Such alternatives need to be understood as components of integrated, long-term livelihood strategies.

Returning to the questions posed at the end of section 15.3, the dire assessment of Sahelian futures that followed the 1970s famines were in fact under-estimations of 'adaptive success' across the Sahel. In fact, few mortalities could be attributed directly to the Sahel drought, and there were less in the 1980s, since that time, bricolage activities had expanded.

\section{[Insert Figure 15.2 around here]}

\subsection{Climate and development aid}

Mortimore (2010) refers to Northern Nigeria, where development aid has been limited and drought adaptation has occurred largely without outside support, when he says 
Sarah Boulter, Jean Palutikof, David Karoly, and Daniela Guitart (eds.) 2013 in press. Natural

Disasters and Adaptation to Climate Change. Cambridge University Press.

'Some 25 years after the Sahel drought seemed to question the very survival of human communities, the farming systems persisted, village populations were stable or increasing, farming and livestock production were integrating and intensifying, and livelihoods were diversifying. Until 2008, visible indicatorsof monetisation and investment were increasing.' (Mortimore, 2010, p. 136)

In contrast, the francophone Sahel has received millions of dollars in aid to increase its resilience to drought since the mid-1970s. Some of this has gone to poor rural communities, ostensibly to reduce vulnerability and alleviate poverty. However, one assessment placed this as only US\$ 45 per person per year by the mid-2000s (Sahel Working Group, 2007, p. 28). Well-targeted development aid can improve resilience to drought and should not be dismissed as an inefficient type of transfer payment (Mortimore, 2010). The restoration of thousands of hectares of remote village farmland in Burkina Faso through soil and water conservation techniques, built by farmers but with some outside logistical and technical support from Oxfam and German and Dutch aid, was positive (Batterbury, 1998). Burkinabè farmers in the drylands of that country have often exploited such project aid to gain additional status and benefits in ways unintended by donors (e.g. to attract a gift of a school or a tube well to a village that was performing well with an existing soil restoration donor), but nonetheless their resilience has been enhanced (Batterbury, 1998).

Paul Richards has argued, following Durkheim, that 'much of what farmers and farm labourers do (as opposed to what science or regulatory authority tells them to do) is based on practical contingencies... or it relates to unavoidable social responsibilities to dependants or a wider community group.' (Richards, 2010, p. 10).

If we make these practical contingencies our starting point in understanding adaptation to climate change, rather than dismissing them as incidental or inefficient, then we throw up an enduring challenge to climate and development policy. We need to recognise structure and agency - by showing sensitivity to the internal adaptive resources of farming and pastoral households as well as recognising the constraints they face, and understanding their autonomous capabilities as well as the external forces bearing upon them.

Meanwhile the international aid sector could place much greater attention on the constraints that Sahelian peoples cannot themselves address under climate change. These include international migration restrictions, and threats to productive activity like cheap food imports to urban centres, unjust land alienation, and weak human and animal health services.

\subsection{Conclusion}

In conclusion, we have argued that the severity of droughts affecting the Sahel have led to practical adaptive strategies emerging, as well as long term adjustments of rural livelihood activities to rainfall deficiencies. Forty years of drought adaptation in the Sahel has been overlooked in contemporary debates over 'adaptation to climate change' that focus most attentively on large scale, public sector adaptation planning, and unjustly polarise regional responses into 'mitigation' or 'adaptation'. Adaptation is not just an issue for the public sector to tackle, and for planners to organise on behalf of local people. It still includes direct responses to climate hazards by poorer members of rural society, with an attendant growth of local knowledge about these hazards. The seriousness of African drought and famine is often noted in 
the climate change literature, but this long-term adaptive strategising, and learning from hardship, have too often been misinterpreted as mere 'coping strategies'.

Sahelian adaptation is much more than this. It has resulted from a combination of skill and technique, both learned and invented, and has been combined with deliberate efforts by households and communities to reduce their vulnerability. There is strong evidence that the response to Sahelian drought over the last forty years, while constrained, is now adequate to the challenge of future climate uncertainty. Adaptation should be facilitated rather than driven from the outside.

\section{Acknowledgements}

Our findings come from residence and field research from 1963 to 1986 in Northern Nigeria (MM), subsequent research projects funded by the ESRC, DfID, World Bank, and SSRC (MM and SB) including three years fieldwork in Burkina Faso and Niger (SB). We acknowledge the comments of two referees.

\section{References}

Adams, W. M. and Mortimore, M. J. (1997). Agricultural intensification and flexibility in the Nigerian Sahel. The Geographical Journal, 163(2), 150-160.

Batterbury, S. P. J. (1998). Local environmental management, land degradation and the 'Gestion des Terroirs' approach in West Africa; policies and pitfalls. Journal of International Development, 10, 871-898.

Batterbury, S. P. J. (2001). Landscapes of diversity: a local political ecology of livelihood diversification in south-western Niger. Ecumene, 8, 437-464.

Batterbury, S. P. J. and Forsyth, T. J. (1999). Fighting back: human adaptations in marginal environments. Environment, 41(6), 6-11.

Bredeloup, S. and Pliez, O. (2011). The Libyan Migration Corridor. San Domenico di Fiesole, Italy: Robert Schuman Centre for Advanced Studies, European University Institute. Retrieved 24 October 2012 from:

$<$ http://www.eui.eu/Projects/TransatlanticProject/Documents/CaseStudies/EUUSImmigrationSystems-Security-CS.pdf>.

Busso C. S., Devos, K. M., Ross, G. et al. (2000). Genetic diversity within and among landraces of pearl millet (Pennisetum glaucum) under farmer management in West Africa. Genetic Resources and Crop Evolution, 47, 561-568.

Castañeda, I. S., Mulitza, S., Schefuss, E. et al. (2009). Wet phases in the Sahara/Sahel region and human migration patterns in North Africa. Proceedings of the National Academy of Sciences, 106, 20159-20163.

Dai, A., Lamb, P. J., Trenberth, K. E. et al. (2004). The Sahel drought is real. International Journal of Climatology, 24, 1323-1331. 
Sarah Boulter, Jean Palutikof, David Karoly, and Daniela Guitart (eds.) 2013 in press. Natural Disasters and Adaptation to Climate Change. Cambridge University Press.

de Leeuw, P. N., Reynolds, L. and Rey, B. (1995). Nutrient transfers in West African agricultural systems. In Livestock and Sustainable Nutrient Cycling in Mixed Farming Systems of Sub-Saharan Africa. Volume II: Technical Papers. Proceedings of an International Conference held in Addis Ababa, Ethiopia, 22-26 November 1993, eds. J. M. Powell, S. Fernandez-Rivera, T. O. Williams and C. Renard. Addis Ababa, Ethiopia: International Livestock Centre for Africa, pp. 371-392.

Giannini, A., Biasutti, M. and Verstraete, M. M. (2008). A climate model-based review of drought in the Sahel: desertification, the re-greening and climate change. Global and Planetary Change, 64, 119-128.

Hilhorst, T., Nelen, J. and Traoré, N. (2011). Agrarian change under the radar screen: rising farmland acquisitions by domestic investors. International Conference on Global Land Grabbing, Sussex, 6-8 April.

Kratli, S. (2008). Time to outbreed animal science? A cattle breeding system exploiting structural unpredictability. the WoDaaBe herders in Niger. STEPS Working Papers No. 7. Brighton, UK: Institute of Development Studies.

Mertz, O., Mbow, C., Østergaard Nielsen, J. et.al. (2010). Climate factors play a limited role for past adaptation strategies in West Africa. Ecology and Society, 15, 25.

Mortimore, M. J. (1989). Adapting to drought: farmers, famines and desertification in West Africa. Cambridge, UK: Cambridge University Press.

Mortimore, M. J. (2006). Managing soil fertility on small family farms in African Drylands. In Biological Approaches to Sustainable Soil Systems, eds. N. Uphoff, A. S. Ball, E. Fernandes, et al. New York: Taylor and Francis, pp. 373-390.

Mortimore, M. J. (2010). Adapting to drought in the Sahel: lessons for climate change. WIREs Climate Change, 1, 134-143.

Mortimore, M. J. and Adams, W. M. (2001). Farmer adaptation, change and 'crisis' in the Sahel. Global Environmental Change, 11, 49-57.

Mulitza, S., Prange, M., Stuut, J.-B. et al. (2008). Sahel megadroughts triggered by glacial slowdowns of Atlantic meridional overturning. Paleoceanography, 23, 1-11.

Richards, P. (2010). A Green Revolution from Below? Science and Technology for Global Food Security and Poverty Alleviation. Wageningen, Netherlands: Wageningen University. Retrieved 24 October 2012 from: <http://edepot.wur.nl/165231>.

Tacko Kandji S., Verchot, L., Mackensen, J. (2006). Climate Change and Variability in the Sahel Region: Impacts and Adaptation Strategies in the Agricultural Sector. Nairobi, Kenya: World Agroforestry Centre and United Nations Environment Programme.

Watts, M. J. (1983). Silent Violence: Food, Famine and the Peasantry in Northern Nigeria. Berkeley, CA, USA: University of California Press. 
Figure captions

Figure 15.1. Long term Sahel rainfall trends (Source: Wikimedia Commons).

Figure 15.2. Typical stepwise diversification of livelihood activities in a rainfed agricultural community in the Sahel. Frequently, multiple activities are practiced in a household, and assets are pooled. Step 1 - combine crops and livestock, Step 2 - add local household business activity, Step 3 - some household members migrate to seek work and remittances. 


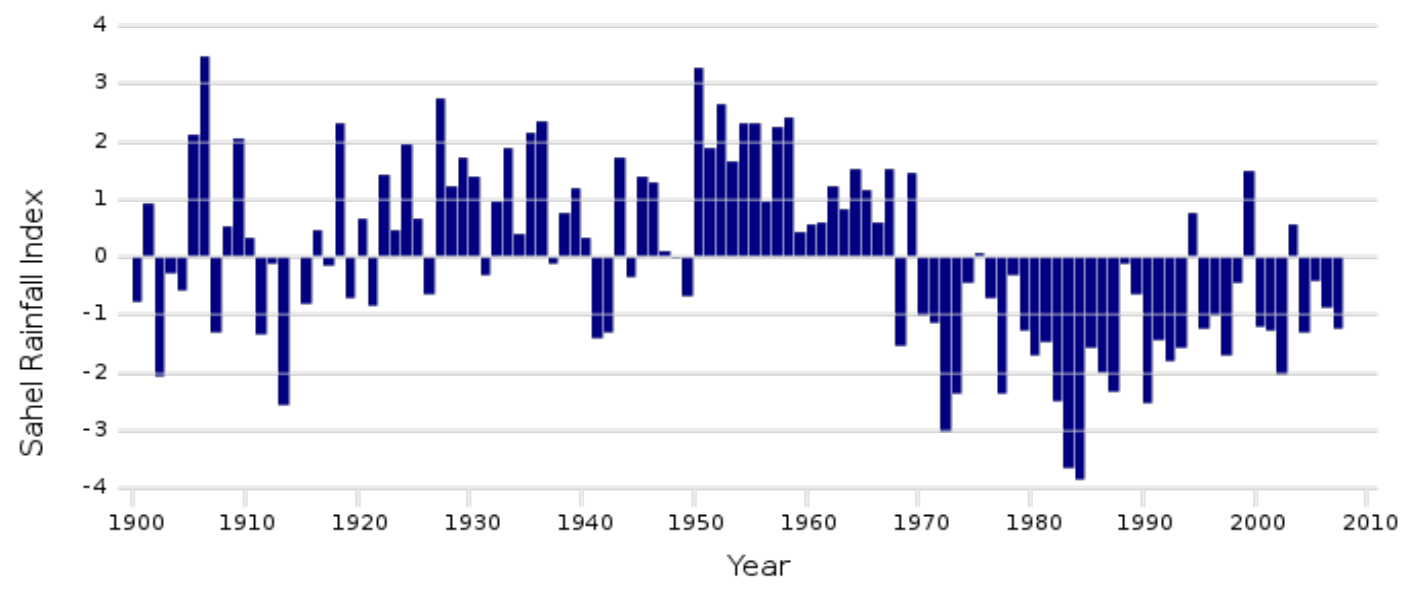

Fig 1. Long term Sahel rainfall trends. Source: Wikimedia Commons, public domain, NASA data http://en.wikipedia.org/wiki/File:Sahel rainfall timeseries en.svg

Any Sahel rain graph will do - not sure where to get a better one from. 
Fig 2. Typical stepwise diversification of livelihood activities in a rainfed agricultural community in the Sahel. Frequently, multiple activities are practiced in a household, and assets are pooled. Source: Authors

(Sorry I don't really know how to format figures)

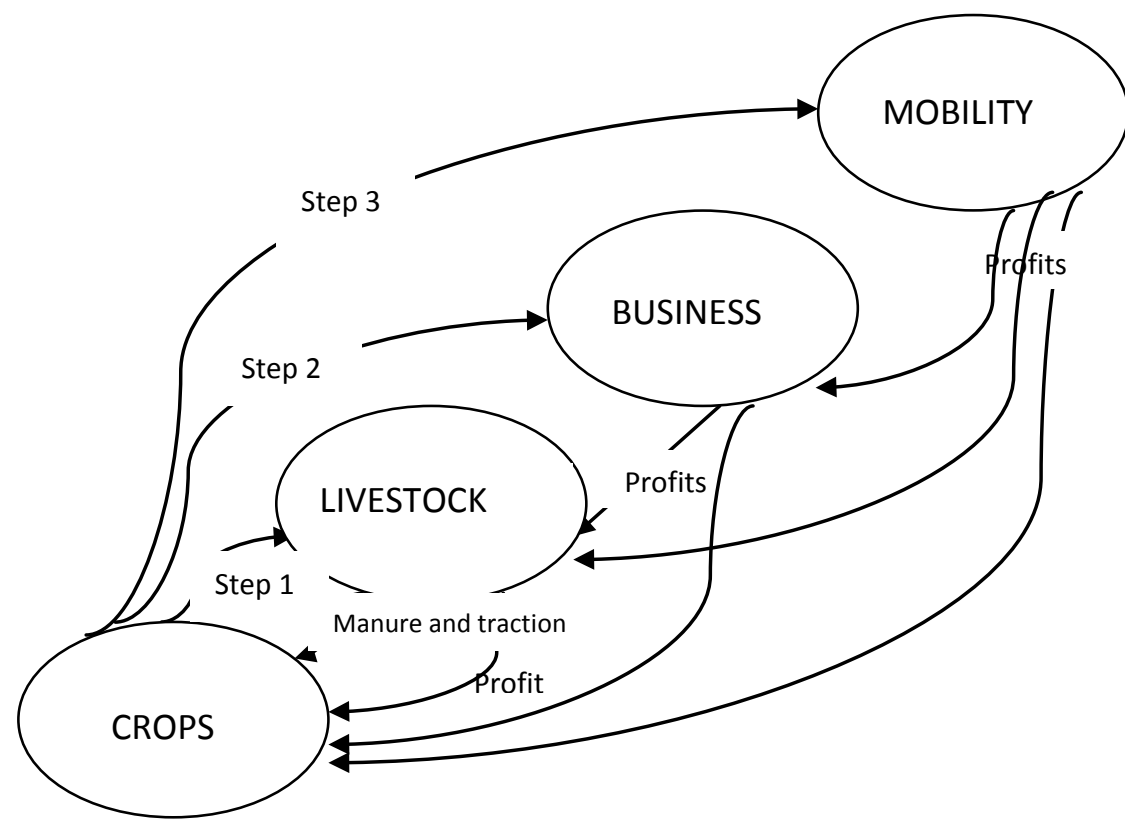

Step 1 - combine crops and livestock

Step 2 - add local household business activity

Step 3 - some household members migrate to seek work and remittances

Increasing drought severity, and degree

of livelihood diversification 